\section{Phytotoxicity Associated with Drip- applied 1,3-Dichloropropene and Chloropicrin in Vegetables Produced with Plastic Mulch}

\author{
Johan Desaeger ${ }^{1}$ and Alex Csinos \\ University of Georgia, Department of Plant Pathology, Coastal Plain \\ Experiment Station, Tifton, GA 31793-0748
}

Additional index words. drip fumigation, soil gas concentrations, Solanaceae, Cucurbitae, plant vigor

Abstract. The effects of drip-applied 1,3-dichloropropene(1,3-D) and chloropicrin on fumigant soil gas levels and growth of vegetable seedlings were investigated in three separate tests in Tifton, Ga. Tests were conducted in Spring 2002, Fall 2002, and Spring 2003. Phytotoxicity of 1,3-D + chloropicrin was induced in the 2002 tests by applying progressively higher rates $\left(0\right.$ to $\left.374 \mathrm{~L} \cdot \mathrm{ha}^{-1}\right)$ of drip-irrigated InLine (an emulsifiable formulation (EC) containing $60.8 \%$ 1,3-D and $33.3 \%$ chloropicrin) and planting vegetable seedlings within four days after application. Vegetables evaluated were tomato, pepper and cucumber (Spring 2002), and tomato and squash (Fall 2002). In Spring 2003, the effects of 1,3-D formulation (InLine versus Telone EC, an EC containing 94\% 1,3-D), plastic mulch type [low density polyethylene (LDPE) versus virtually impermeable film (VIF)] and drip tape configuration (one versus two drip tapes) on fumigant soil gas levels and growth of tomato were investigated. Tomato was planted after the recommended 3-week waiting period. Fumigant concentrations in soil were measured using Gastec detection tubes at 1 to 4 days after drip fumigation in all three tests. Measured fumigant soil gas concentrations were correlated with fumigant application rates in Spring 2002, but not in Fall 2002. Vegetables were visibly affected by residual fumigant levels in the soil and showed symptoms such as leaf chlorosis (cucumber, squash and pepper), leaf bronzing (tomato) and stem browning and stunting (all crops). Fumigant soil air levels were negatively and linearly correlated with different plant growth parameters, in particular plant vigor. The cucurbit crops showed an immediate response and high mortality within 1 week after planting. Surviving plants recovered well in fall. The solanaceous crops showed a more delayed response and lower mortality rates. However, phytotoxic effects with tomato and pepper were more persistent and plants did not seem to recover with time. Overall, fumigant residue levels and potential phytotoxicity were greater in spring than in fall. Greater fumigant soil concentrations were measured under VIF as compared to LDPE plastic mulch. The effect of drip-tape configuration varied with the type of plastic mulch that was used. The double-tape treatment resulted in lower fumigant levels at the bed center under LDPE mulch, and higher fumigant levels at the bed shoulder under VIF mulch. The formulation containing 94\% 1,3-D resulted in higher soil fumigant levels as compared to the formulation containing $61 \% 1,3-\mathrm{D}$ and $33 \%$ chloropicrin, especially with VIF mulch. Early plant vigor of tomato was negatively correlated with fumigant soil gas levels, and was especially poor following drip fumigation with 94\% 1,3-D under VIF mulch.

Drip-irrigation tubing (drip tubes) is widely used for delivery of water and fertilizer in polyethylenefilm-mulchedbeds (plasticulture), especially by vegetable growers (Camp, 1998). Drip irrigation systems can also be used to apply emulsifiable formulations of soil fumigants, a technique that has received increased interest with the pending discontinuation of methyl bromide(Ajwa etal., 2002; Noling, 1991; Overman, 1982). Soil fumigation through drip tubes offers many benefits over the traditional practice of chisel injection. It increases a grower's flexibility, reduces the potential for worker exposure

Received for publication 9 June 2004. Accepted for publication $30 \mathrm{Aug}$. 2004. The authors wish to thank Joe Eger and Dow AgroSciences for financial assistance and Jimmy Laska, Chris Williamson, Tonya Jo Cravens, Don Hickey, Unessee Hargett and Lewis Mullis for technical assistance. ${ }^{1}$ Corresponding author. third crops and practically can only be controlled by applying preplant pesticides through the drip tape. Some of the more promising pre-plant fumigants for nematode control in plasticulture are emulsifiable formulations of 1,3-dichloropropene (1,3-D). Two emulsifiable 1,3-D formulations are currently labeled for drip fumigation in plasticulture, InLine $(60.8 \%$ 1,3-D and 33.3\% chloropicrin) and Telone EC (94\% 1,3-D) (Dow AgroSciences, 2004). As a general rule, chisel-injected 1,3-D requires a waiting period between fumigation and planting of about 1 week for each $100 \mathrm{~L} \cdot \mathrm{ha}^{-1}$, and in practice a 14-d interval is recommended (Georgia Automated Enviromental Monitoring Network, 2004). However, breakdown and volatilization of 1,3-D depends on many factors, including temperature, soil type, plastic mulch type and application rate and formulation. The required waiting period following application of 1,3-D therefore may be difficult to predict, and as far as we know, no data are available on persistence of emulsified 1,3-D in plastic mulch beds. Most research into alternatives to methyl bromide has concentrated on efficacy. However, the increased potential of phytotoxicity with chemicals such as 1,3-dichloropropene may be of greater concern to growers than the increments in pest pressure due to loss of methyl bromide.

The objectives of this study were 1) to quantify 1,3-D + chloropicrin gas levels in plastic mulched beds as affected by application rate, plastic mulch type and drip tape configuration, and 2) to compare different vegetable crops for their sensitivity to residual 1,3-D + chloropicrin following spring and fall applications. The selected vegetables were cucumber (Cucumis sativus L.), squash (Cucurbita pepo L.), pepper (Capsicum annum L.), and tomato (Lycopersicon esculentum L.).

\section{Materials and Methods}

Site description and land preparation

Tests were conducted between Spring 2002 and Summer 2003 at the University of Georgia's Coastal Plain Experiment Station, Tifton, on a Fuquay loamy sand (88\% sand, $8 \%$ silt, $4 \%$ clay; $\mathrm{pH} 5.5$ to $6.0 ;<2 \%$ organic matter; loamy, siliceous thermic Arenic Plinthic Paleudult). The test area had a history of vegetable crops prior to initiation of the studies. Plant beds were formed using a commercial tractor-drawn bed-former (Kennco, Ruskin, Fla.) when the soil was between $60 \%$ to $80 \%$ field capacity, either after a rain or moistened with overhead irrigation to ensure proper bed formation. Soil moisture was determined with the gravimetric method (Brady, 1974). Before bed formation, the soil was disc-harrowed and turned 25 to 30 $\mathrm{cm}$ deep with a moldboard plow. Beds were 9.1 $\mathrm{m}$ long, $76 \mathrm{~cm}$ wide $\times 15$ to $18 \mathrm{~cm}$ tall, with $1.82-\mathrm{m}$ spacing, center to center of the beds and a 3.8-m-wide alley between replications. Plots were replicated five times in a randomized complete block design.

\section{General management practices}

Irrigation. Drip tape was installed 2 to 4 $\mathrm{cm}$ below the surface of the beds as the plastic mulch was applied. Drip tape was installed in 
the center of the bed for single-tape treatments, and halfway between center and shoulder (19 $\mathrm{cm}$ from each shoulder) for the double-tape treatments. Aqua-Traxx (Toro Co, El Cajon) premium high-flow drip tape was used in the 2002 tests, and T-Tape (T-Systems, San Diego) was used in the 2003 tests. Both drip tapes had $30.48-\mathrm{cm}$ spacing between emitters and a flow rate of $1.14 \mathrm{~L} \cdot \mathrm{h}^{-1}$ at $0.69 \mathrm{bar}$ pressure. Irrigation water was applied every day or every second day depending on the need.

Fertilization. Experimental areas were broadcast-fertilized with N-P-K fertilizer (10 4.4-8.2) before treatment application at a rate of $600 \mathrm{~kg} \cdot \mathrm{ha}^{-1}$, and fertilizer was incorporated with a rototiller about $10 \mathrm{~cm}$ deep. Postplant fertilizer (20-8.8-16.6 alternating with4-0-6.6) was applied through the drip system in equal applications once or twice a week depending on the need, according to the Georgia Cooperative Extension Service recommendations(Granberry et al., 1996).

Fumigation. Methyl bromide (67\% methyl bromide a.i. $+33 \%$ chloropicrin a.i.; Hendrix and Dail) was applied with a tractor-drawn chisel injector in Spring 2003. The chisel injector had shanks spaced $30 \mathrm{~cm}$ apart for injecting chemicals 20 to $25 \mathrm{~cm}$ deep. 1,3-D (as Telone EC; 94\% 1,3-D a.i., or as InLine; $60.8 \%$ 1,3-D a.i. $+33.3 \%$ chloropicrin a.i.; Dow AgroSciences) was injected through the irrigation system with an injection pump over 5 to $6 \mathrm{~h}$, in 20 to $25 \mathrm{~L}$ of water $/ \mathrm{m}^{2}$. Immediately after each drip application, the drip system in each plot was allowed to run an additional $30 \mathrm{~min}$ to purge remaining chemical from drip tubes.

Fungicide, insecticide and herbicide applications. Foliar applied fungicides were sprayed once or twice a week depending on the need. Copper hydroxide (as Kocide 4.5 LF; 37.5\% a.i.; Griffin) was applied at $0.96 \mathrm{~L} \cdot \mathrm{ha}^{-1}$ a.i., mancozeb (as Dithane DF; 75\% a.i.; Rohm and Haas) at $0.69 \mathrm{~kg} \cdot \mathrm{ha}^{-1}$ a.i and chlorothalonil (as Equus $720 ; 54 \%$ a.i.; Griffin) at $0.21 \mathrm{~L}^{-} \mathrm{ha}^{-1}$ a.i. Insecticides \{permethrin (as Pounce, 38.4\% a.i.; FMC) at $0.12 \mathrm{~L} \cdot \mathrm{ha}^{-1}$ a.i., esfenvalerate (as Asana XL; $8.4 \%$ a.i.; DuPont) at $0.08 \mathrm{~L} \cdot \mathrm{ha}^{-1}$ a.i., methomyl (as Lannate LV; $29 \%$ a.i.; DuPont) at $0.40 \mathrm{~L} \cdot \mathrm{ha}^{-1}$ a.i. and spinosad (as Spintor 2SC; $22.8 \%$ a.i.; Dow AgroSciences) at $0.15 \mathrm{~L}^{2} \mathrm{ha}^{-1}$ a.i.\} were sprayed with the same frequency. In the Spring 2003 test, trifluralin (as Treflan HFP; $43 \%$ a.i.; Dow AgroSciences) at $0.14 \mathrm{~kg} \cdot \mathrm{ha}^{-1}$ a.i. was applied ahead of bed formation on all plots receiving 1,3-D. Glyphosate (as RoundUp; $41 \%$ a.i.; Monsanto) at $0.50 \mathrm{~L} \cdot \mathrm{ha}^{-1}$ a.i. was sprayed in between beds to control weeds as required.

\section{Data collection and analysis}

Concentrations of 1,3-D and chloropicrin in soil were measured using the Gastec 132HA (scale range $=50$ to $500 \mathrm{mg} \cdot \mathrm{L}^{-1}$ ) and $132 \mathrm{~L}$ (scale range $=2$ to $25 \mathrm{mg} \cdot \mathrm{L}^{-1}$ ) detection tubes. These tubes measure trichloroethylene and do not differentiate between 1,3-D and chloropicrin. Therefore, the measured concentrations will be referred to as fumigants and are total concentrations for both 1,3-D and chloropicrin (InLine). Readings from Gastec tubes are not quantitative and are therefore not presented in $\mathrm{mg} \cdot \mathrm{L}^{-1}$ but rather as relative concentrations $(\%$ relative to initial concentration at $0 \mathrm{~cm}$ depth) and will be referred to as relative fumigant concentrations (RFC). The actual measurement range of these tubes depends on the amount of air that is drawn and ranges from 20 to 1300 $\mathrm{mg} \cdot \mathrm{L}^{-1}(132 \mathrm{HA})$ and from 1 to $70 \mathrm{mg} \cdot \mathrm{L}^{-1}(132 \mathrm{~L})$. Lower limits of detection (LOD) are $4 \mathrm{mg} \cdot \mathrm{L}^{-1}$ for the $132 \mathrm{HA}$ tubes and $0.4 \mathrm{mg} \cdot \mathrm{L}^{-1}$ for the $132 \mathrm{~L}$ tubes. Measurements were taken from a 1.25 -cm-diameter, $15-\mathrm{cm}$-deep hole cored into the bed at each location. A gas detection pump (model AP-1S; Sensidyne) was used to draw 50 to $200 \mathrm{~mL}$ of air, depending on sensitivity of the tube and levels present in the soil, from each hole through the detection tube. A soil temperature probe was inserted into one bed at each site just before injections were done and retrieved at termination of the tests.

Plant stand counts were taken at one, three, nine and $14 \mathrm{~d}$ after planting (DAP), and every week afterwards. Plant vigor ratings were recorded at 1 week after planting(WAP) and every week afterward on a 1 to 10 scale, where $10=$ vigorous, healthy plants and $1=$ dead plants. Flowering incidence and plant height was evaluated in the 2002 spring test at four WAP. The number of wilted plants was counted in the Fall 2002 test at 4 and 8 DAP and the number of stunted plants in the 2003 spring test at 35 DAP. Fresh root and shoot weights were taken after 50 days in Spring 2002, after 28 d in Fall 2002, and after 40 d in Spring 2003.

All data were analyzed using ANOVA or GLM procedures with SAS software (version 8 ). Means were compared using Fisher's protected least significant difference (FLSD) test $(P \leq 0.05)$. Single-degree-of-freedom contrasts were used to compare means for plastic mulch type, 1,3-D formulation and drip tape configuration. Linear regressions were fitted with plant growth parameters as the dependent variable and fumigant soil gas concentrations or application rates as the independent variables.

\section{Treatments}

Tests 1-2. effect of growing season, application rate and vegetable type. Tests were conducted in spring (April-May) and fall (September-October) 2002. Plots were arranged as split plots, with application rates as main plots (9.1-m-long beds) and vegetable crops as subplots. Main plots were replicated five times in a Randomized Complete Block Design. Subplots were completely randomized within each main plot. Plastic mulch was black LDPE (low-density polyethylene, $50 \mu \mathrm{m}$ thick, PlastiTech) in spring and clear LDPE $(100 \mu \mathrm{m}$ thickness, PlastiTech) in fall. Application rates of InLine were 0, 18.7, 37.4, 93.5, 187, 281, and $374 \mathrm{~L} \cdot \mathrm{ha}^{-1}$ in spring and $0,37.4,93.5,187$, 281 , and $374 \mathrm{~L} \cdot \mathrm{ha}^{-1}$ in fall. Spring applications were made on 1 to 2 Apr., and fall applications on 16 to 18 Sept., with the highest rates being applied first. Soil gas samples were taken one and two days after the final drip application in spring, and one day after the final application in fall. In spring, samples were drawn from three arbitrarily selected locations in the center of the bed. In fall, two samples were taken from randomly selected positions halfway between two emitters. Emitter location was determined by adding a blue agricultural dye (Highlight) to the chemical drip solution prior to application (Csinos et al., 2002a). Emitter location was visualized by the emerging circular blue dye patterns, which could be seen through the clear plastic mulch.

Vegetable seedlings were produced in the greenhouse in plug trays and were planted at the four-leaf stage in single rows adjacent to the drip tape using a hole-puncher combined with a mechanical hand-transplanter and water tank. Vegetables were planted 3 to $4 \mathrm{~d}$ after fumigation (DAF) on 5 Apr., in spring, and 1 to $3 \mathrm{DAF}$ on 19 Sept., in fall. Each subplot consisted of one vegetable plot having seven seedlings in spring and 12 seedlings in fall. Plant spacing was $30 \mathrm{~cm}$ between plants and $60 \mathrm{~cm}$ between subplots. In spring, cucumber (Cucumis sativus L. 'General Lee'), pepper (Capsicum annuum L. 'Capistrano') and tomato (Lycopersicon esculentum Mill.'BHN-444') were planted. In fall, tomato ('BHN-444') and squash (Cucurbita pepo L. 'Destiny III') were planted.

Test 2. effect of plastic mulch, drip tape

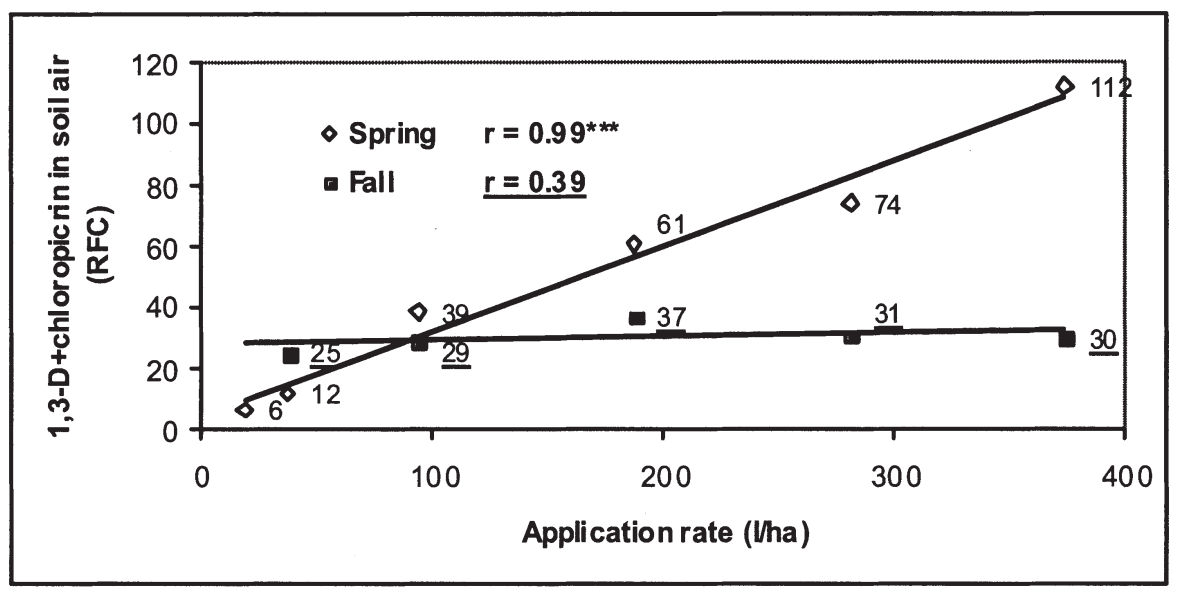

Fig. 1. Correlation between application rates of 1,3-D + chloropicrin and soil air concentrations of 1,3-D + chloropicrin at 1 to $3 \mathrm{~d}$ after application during spring and fall, Tifton, Ga., in 2002. Concentrations are relative fumigant concentrations (RFC) expressed as \% relative to initial concentration at $0 \mathrm{~cm}$ depth. ${ }^{* * *} P<0.001$ 
configuration and 1,3-D formulation. The test was in Spring 2003. On 28 March, herbicide (trifluralin at $0.14 \mathrm{~kg} \cdot \mathrm{ha}^{-1}$ a.i.) and methyl bromide (at $336 \mathrm{~kg} \cdot \mathrm{ha}^{-1}$ ) were applied to designated plots and beds were immediately covered with black polyethylene plastic mulch (LDPE) (Table 5). Beds that were to receive 1,3-D were also covered. Two types of plastic mulch were used: low-density polyethylene (LDPE; thickness $50 \mu \mathrm{m}$, PlastiTech) and virtually impermeable film (VIF; a mixture of polyethylene with vinylchlorides; thickness 35 $\mu \mathrm{m}$, permeability to methyl bromide $0.02 \mathrm{~g} \cdot \mathrm{m}^{-2}$ $\times \mathrm{h}$, IPM, Italy). Drip tape was installed about 2 to $4 \mathrm{~cm}$ deep as the polyethylene mulch was applied. Methyl bromide and nontreated plots received one drip tape in the center of the bed. In beds that were to be fumigated with 1,3-D, in addition to the single-tape treatment, also a double-tape treatment was included whereby each tape was located $19 \mathrm{~cm}$ from the shoulder of the bed. The 1,3-D drip tape injection treatments were started on 29 Mar. and injections were finished on 4 Apr. Two formulations were applied and application rates were such that similar amounts of 1,3-D $\left(199 \mathrm{~L} \cdot \mathrm{ha}^{-1}\right.$ a.i. 1,3-D) were injected: the $94 \% 1,3-\mathrm{D}$ emulsion (Telone EC) was applied at $212 \mathrm{~L} \cdot \mathrm{ha}^{-1}$ and the emulsifiable formulation containing
$60.8 \% 1,3-\mathrm{D}$ and $33.3 \%$ chloropicrin (InLine) at $327 \mathrm{~L} \cdot \mathrm{ha}^{-1}$.

Fumigant concentrations were measured using the Gastec system on 5 and 8 Apr. (at 1 and $4 \mathrm{~d}$ after the final drip injection) as mentioned earlier for the Fall 2002 test. Each day measurements were taken in the bed center $(1 \mathrm{~cm}$ from the drip tape), midway between bed center and bed shoulder (18 $\mathrm{cm}$ from the drip tape) and at the bed shoulder (36 $\mathrm{cm}$ from the drip tape). Vegetable seedlings were produced and planted as previously described. Planting holes were made on 21 Apr. and $4 \mathrm{~d}$ later, on $25 \mathrm{Apr}$., 'Amelia' tomato seedlings were transplanted spaced $45 \mathrm{~cm}$ apart. Dead or dying seedlings were replaced over the first week.

\section{Results}

Effect of growing season, application rate and vegetable type. Soil gas concentrations [relative fumigant concentration (RFC)] of InLine averaged from 6 to 112 RFC in spring and from 25 to 37 RFC in fall (Fig. 1). Soil gas concentrations were positively correlated to actual application rates in spring, but not in fall (Fig. 1). Phytotoxicity varied with vegetable crop and growing season. Cucumber and squash showed yellowing, curling and dehydra- tion of the leaves. Pepper showed leaf chlorosis and tomato leaves showed bronzing (in spring) and black lesions (in fall). Stem symptoms ranged from constricting (cucumber), darkening (tomato and pepper) to lodging (all crops). Plant survival progressively decreased with increasing fumigant application rates (Fig. 2 ). The cucurbit crops, cucumber and squash, showed an immediate response to fumigant application rates. By $3 \mathrm{~d}$ after planting (DAP) $29 \%$ of cucumber plants (spring) and $15 \%$ of squash plants (fall) had died. Plant mortality increased over the following weeks, and by 21 DAPup to $69 \%$ of cucumber and $46 \%$ of squash plants had died (Fig. 2A and D). In contrast, the solanaceous crops, tomato and pepper, showed a more delayed response and no plant mortality was noted at three DAP (Fig. 2B, C, and E). However, significant plant mortality occurred after this and by 21 DAP pepper had a maximum mortality rate of $40 \%$, while tomato mortality was maximum $23 \%$ in spring and up to $50 \%$ in fall (Fig. 2B, C, and E).

Several plant growth parameters were negatively correlated with soil fumigant concentrations and/or fumigant application rates (Figs. 3 and 4). In spring, regressions are given with measured fumigant soil gas levels $[\log (\mathrm{x}+1)]$ as the independent variable (Fig. 3). In fall,
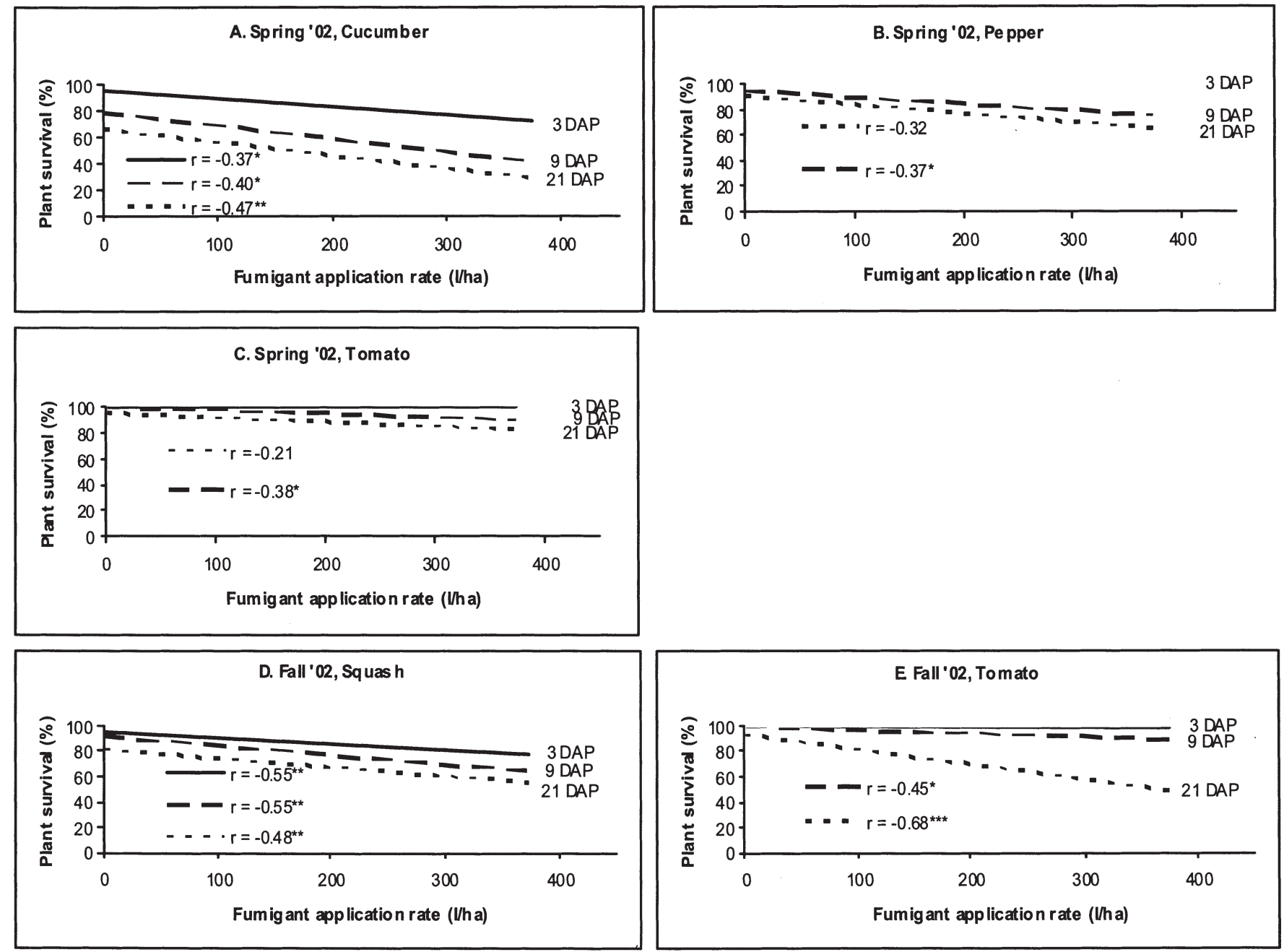

Fig. 2. Linear regressions and correlation coefficients $(r)$ between fumigant (1,3-D + chloropicrin) application rates and plant survival of tomato, pepper, cucumber and squash following drip fumigation with InLine in polyethylene mulch beds, spring/Fall 2002, Tifton, Ga.; $\mathrm{n}=35$ (spring), $\mathrm{n}=30$ (fall); DAP = days after planting. ${ }^{*} P<0.05,{ }^{* * *} P<0.01,{ }^{* * *} P<0.001$ 


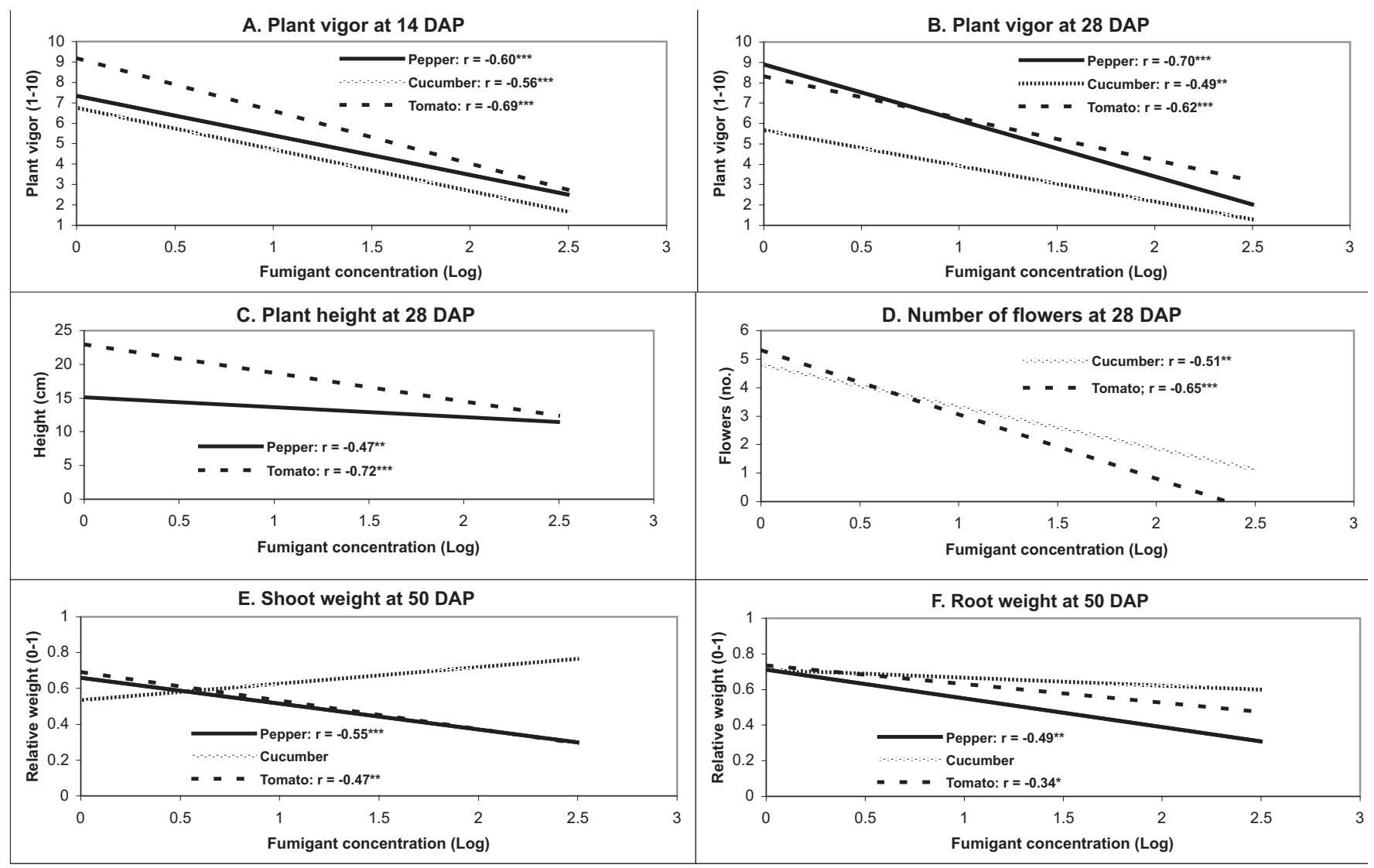

Fig. 3. Linear regressions and correlation coefficients $(r)$ between fumigant (1,3-D + chloropicrin) concentrations in soil air $(\log +1)$ and plant growth of tomato, pepper and cucumber following drip fumigation with InLine in polyethylene mulch beds, spring 2002, Tifton, Ga.; $\mathrm{n}=35$; DAP $=$ days after planting. Concentrations are relative fumigant concentrations (RFC) expressed as \% relative to initial concentration at $0 \mathrm{~cm}$ depth. ${ }^{*} P<0.05,{ }^{* * *} P<0.01,{ }^{* * * *} P<0.001$.

measured fumigant concentrations in soil air were poorly related to actual application rates (Fig. 1), and regressions are given using actual application rates as the independent variable (Fig. 4). Plant vigor ratings at 14 DAP were similarly affected for all crops, but by 28 DAP most significant regressions were noted for the solanaceous crops (Fig. 3A and B, $P<0.001$ ). By 28DAP, fumigants also reduced plant height of pepper and tomato, and flowering incidence of cucumber and tomato (Fig. 3C and D). No flowers were observed on pepper at that time. Shoot and root fresh weights per plant at 50 DAP were still reduced for tomato and pepper, but no longer for cucumber (Fig. 3E and F). In fall both squash and tomato showed reduced plant vigor at 14 and 28 DAP, but reductions were more significant for tomato (Fig. 4A and B). Plant wilting with increasing fumigant application rates at $4 \mathrm{DAP}$ was more prevalent in squash than in tomato (Fig. 4C). However, by 8 DAP wilting of squash was no longer affected by fumigation, whereas in case of tomato the effect of fumigant application rates on wilting became stronger (Fig. 4D). Shoot fresh weights per plant at 28 DAP were negatively affected for both squash and especially tomato, but root fresh weights were only reduced for tomato (Fig. 4E and F).

Effect of plastic mulch, drip tape configuration and 1,3-D formulation. Fumigant soil gas concentrations were two- to five-fold greater under VIF as compared to LDPE mulch (Table
$1, P<0.01$ for all VIF-LDPE comparisons). Differences between VIF and LDPE were similar at one and four days after fumigation. Fumigant levels with VIF and LDPE were on average respectively $298 \mathrm{RFC}$ and $95 \mathrm{RFC}$ at 1 $\mathrm{d}$ after fumigation, and 81 and $25 \mathrm{RFC}$ at four days after fumigation. Significant differences in fumigant soil gas levels with VIF and LDPE were still observed $14 \mathrm{~d}$ after drip fumigation (fumigant residue on average $40 \mathrm{RFC}$ with VIF as compared to $5 \mathrm{RFC}$ with LDPE, $P<0.01$, data not given). Increments due to VIF mulch were greatest at the bed shoulders (4- to 5-fold higher fumigant levels), and were similar at the bed center and halfway between center and shoulder (2- to 4-fold increments). Mulch type did notaffect soil temperature, which was similar at around 27 to $29^{\circ} \mathrm{C}$. Application rates for both formulations were adjusted to achieve similar inputs of 1,3-D, but the Telone EC formulation (containing 94\% 1,3-D) resulted in higher fumigant soil gas levels as compared to the InLine formulation (containing 61\% 1,3-D and 33\% chloropicrin) (Table 1). This was especially the case at one day after fumigation and at the bed center. The effect of drip-tape configuration varied with the type of plastic mulch used. The double-tape treatment resulted in lower soil air concentrations at the bed center under LDPE mulch, and higher fumigant levels at the bed shoulder under VIF mulch (Table 1).

Tomato plant vigor ratings and tomato root and shoot weights were negatively correlated with fumigant soil gas levels (Fig. 5A and B). Stunting of tomato plants showed a positive correlation with fumigant soil gas levels (Fig. $5 \mathrm{~A}$ ). The treatment recording the highest soil fumigant gas levels (Telone EC with VIF, Table 1) also recorded the highest incidence of stunted plants with $38 \%$ of tomato plants being stunted.

\section{Discussion}

Higher soil fumigant concentrations in spring as compared to fall were likely due to different air temperatures, which were on average $10^{\circ} \mathrm{C}$ higher in fall than in spring. This resulted in faster decomposition and volatilization of the fumigants and has been documented by others (e.g., Papiernik and Yates, 2001; Ma et al., 2001). Moreover, the permeability of polyethylene (PE) mulch increases with higher temperatures, further accelerating fumigant losses through the mulch in fall (Kolbezen and Abu El-Haj, 1977). The use of clear PE mulch in fall exacerbated this effect as clear PE mulch tends to increase soil temperature over black PE mulch with on average $3.5^{\circ} \mathrm{C}$ (Lamont, 1993). Application rates in fall therefore were subject to rapid degradation and resulted in relatively low fumigant soil gas levels.

Development and severity of phytotoxicity varied considerably with crops. Phytotoxicity effects were noted immediately after planting for the fast-growing cucurbit crops, but effects 

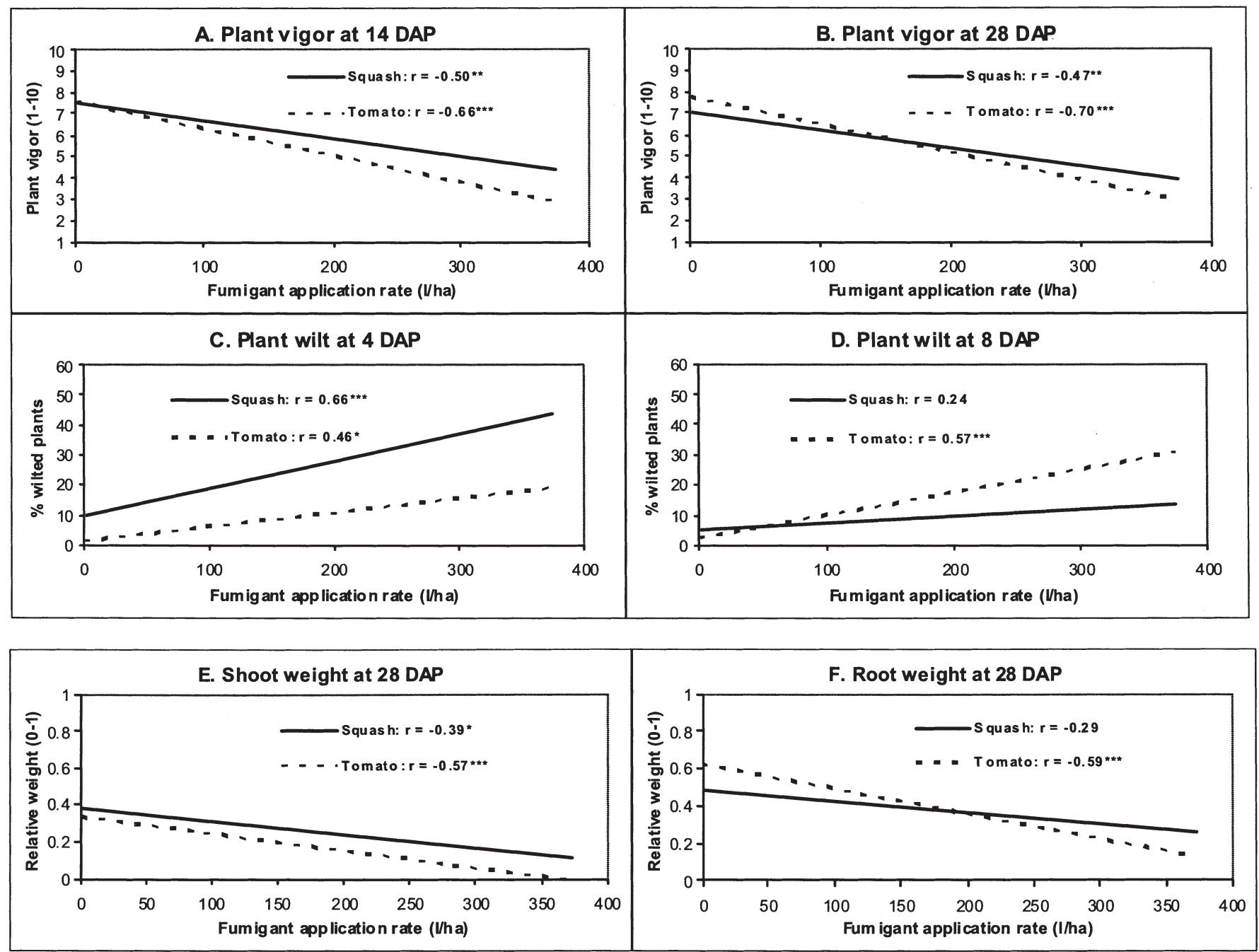

Fig. 4. Linear regressions and correlation coefficients $(r)$ between fumigant $(1,3-\mathrm{D}+$ chloropicrin) application rates and plant growth parameters of tomato and squash following drip fumigation with InLine in polyethylene mulch beds, Fall 2002, Tifton, Ga.; $\mathrm{n}=30$; DAP $=$ days after planting. ${ }^{*} P<0.05,{ }^{* *} P<0.01$, ${ }^{* * * *} P<0.001$

were relatively short-term and surviving plants recovered well, especially in fall. The slowergrowing solanaceous crops, tomato and pepper, showed a more delayed response, but negative effects were more persistent.

Overall, phytotoxicity in spring was noted with fumigant soil gas levels exceeding 12 RFC or with application rates of $\geq 37.4 \mathrm{~L} \cdot \mathrm{ha}^{-1}$. Phytotoxicity threshold levels in spring confirm results from a previous study in Tifton, Ga. (Csinos et al., 2002), where fumigant residues of 10 RFC or more were inversely related to the stand and vigor of seeded tobacco and tomato. The same study (Csinos et al., 2002) also indicated that soil gas sampling from 1,3-D-fumigated beds using the Sensidyne Gastec system was a better measure of potential crop phytotoxicity than the use of lettuce seed germination bioassay. Overall, greater residual fumigant soil gas levels and consequent potential for phytotoxicity were noted in spring than in fall. Application rates as low as $37.4 \mathrm{~L} \cdot \mathrm{ha}^{-1}$ caused phytotoxicity in spring, but not in fall, when application rates of $\geq 93.5 \mathrm{~L} \cdot \mathrm{ha}^{-1}$ were required. Although it is possible to have a warm dry spring and wet cool fall in south Georgia, temperatures over the past 90 years were on average $12{ }^{\circ} \mathrm{C}$ lower in spring (March tp April) than in fall (August to September)(GeorgiaAutomated Enviromental Monitoring Network, 2004). Aeration times in spring therefore will have to be longer than in fall, and early spring planting may have to be delayed to allow the fumigant time to diffuse and break down to a level that will not cause phytotoxicity. Applications in fall are less likely to result in phytotoxicity as soil temperatures and moisture levels are more favorable.

The use of VIF instead of LDPE increased fumigant concentrations in soil air consistently. Volatilization losses through LDPE mulch are high, and it is estimated that $20 \%$ to $30 \%$ of the applied 1,3-D escapes into the air (Chen et al., 1995; Leistra and Frissel, 1975). VIF mulch is primarily $\mathrm{PE}$ mulch mixed with vinylchloride and is much less permeable to 1,3-D and chloropicrin than regular PE mulches (Noling, 2002; Papiernik and Yates, 2001). The use of VIF not only reduced volatilization losses, but also enhanced lateral distribution of fumigants in the bed, confirming similar reports from Florida (Chellemi and Mirusso, 2002). The latter is important in the sandy soils of the southeastern U.S., which have demonstrated poor lateral movement of water (Csinos et al, 2002; Desaeger et al., 2004). Fumigant levels at the bed shoulders that we observed with VIF mulch are within the range required to control nutsedge (Desaeger et al., 2004). Therefore, the use of VIF could be a valuable tool in improving the effectiveness of drip-applied fumigants in the sandy soils of the southeastern U.S. However, by reducing volatilization losses, VIF mulch also increases the potential for phytotoxicity. In our test, $199 \mathrm{~L} \cdot \mathrm{ha}^{-1}$ a.i. of 1,3-D was applied $25 \mathrm{~d}$ before planting of tomato. Holes were cut in the mulch $4 \mathrm{~d}$ ahead of planting to allow for residual chemical to dissipate, but phytotoxicity problems, up to $38 \%$ stunted plants in $1,3-\mathrm{D}$-fumigated plots as compared to $<5 \%$ in nonfumigated and methyl bromide-fumigated plots, were still observed. Cutting planting holes earlier (10 to $14 \mathrm{~d}$ after fumigation) and lowering chemical application rates, especially with VIF mulch, should therefore be recommended to reduce the risk of phytotoxicity for spring-planted crops. In Florida, the use of VIF enabled fumigant application rates to be reduced by $50 \%$ without loss of efficacy (Noling et al., 2001). This, however, only compensates for the additional cost of VIF, which ranges from $\$ 250$ to $\$ 750 /$ ha (Noling, 2002). Unless VIF becomes cheaper in the U.S., growers will not 
be tempted to shift to this type of film.

It is not clear why, despite having similar inputs of 1,3-D, Telone EC resulted in higher fumigant soil gas levels as compared to InLine. Possibly the presence of chloropicrin increased 1,3-D degradation or increased the permeability of the plastic mulch. Higher fumigant concentrations following 1,3-D only as compared to 1,3-D + chloropicrin, and highest incidence of stunting following drip fumigation with 1,3-D only under VIF, also indicate that phytotoxicity was largely due to $1,3-\mathrm{D}$
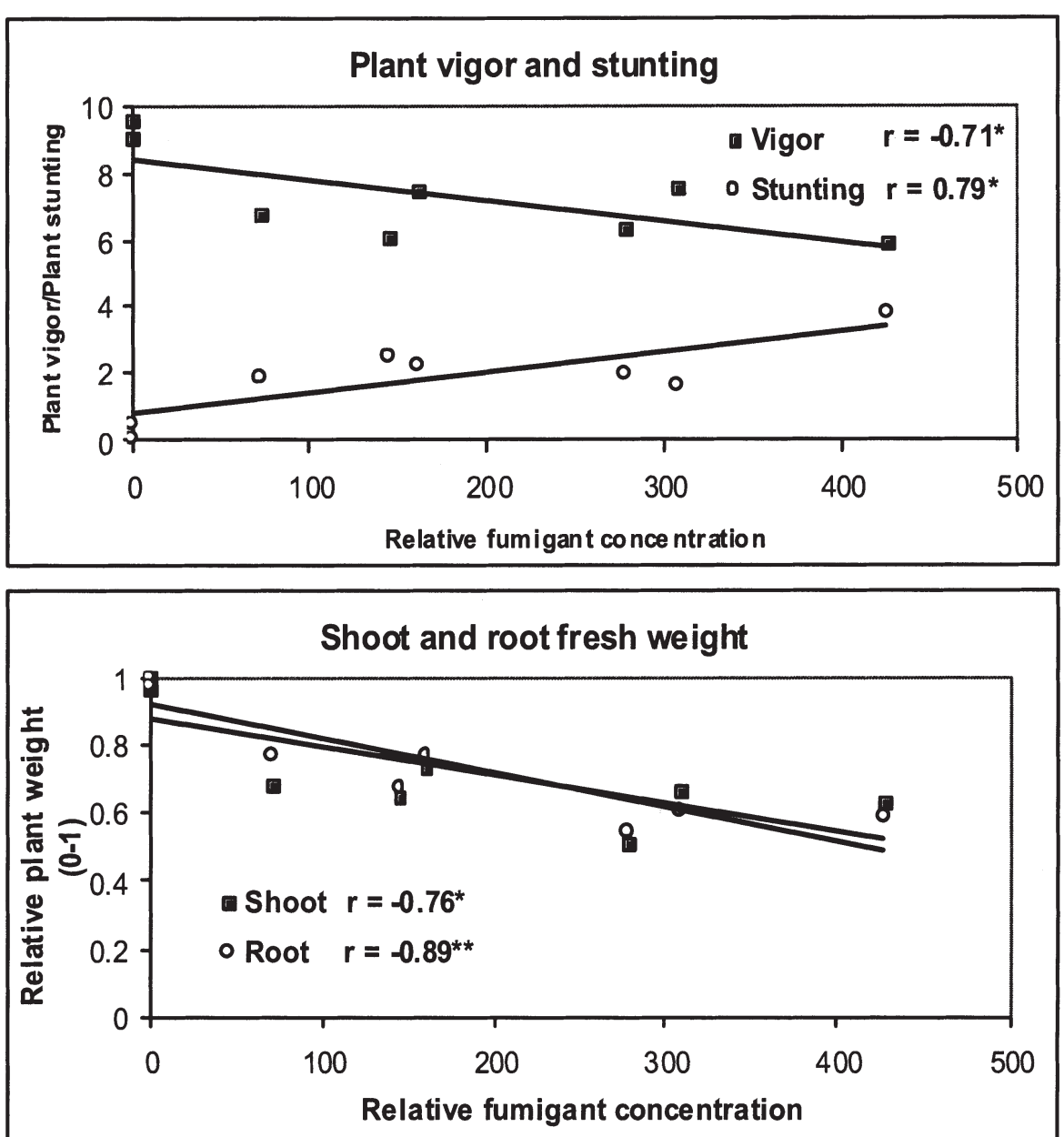

Fig. 5. Linear regressions between fumigant (1,3-D + chloropicrin) concentrations in soil air at 1 DAF (center of the bed) and plant vigor and stunting at $35 \mathrm{DAP}$ (top) and root and shoot weight at 40 DAP (bottom) of tomato following drip fumigation with Telone EC and InLine in polyethylene mulch beds, Spring 2003, Tifton, Ga. DAP = days after planting; DAF = days after fumigation. Concentrations are relative fumigant concentrations (RFC) expressed as $\%$ relative to initial concentration at $0 \mathrm{~cm}$ depth. ${ }^{*} P<0.05,{ }^{* *} P<01$.

and not chloropicrin. Chloropicrin degrades more rapidly in soil than 1,3-D (Gan et al., 2004), and it is therefore less likely to cause phytotoxicity than 1,3-D.

The double-tape treatment resulted in more uniform fumigant levels over the entire bed and lower peak levels at the bed center. The latter would reduce the potential for phytotoxicity when seedlings are planted in or close to the bed center, as is the case for most single-row crops. In our test, however, application rates were high, and fumigant levels at the bed center of the double-tape treatment were still high and did not significantly reduce phytotoxicity. A major constraint for the adoption of double-tape drip configurations is the additional cost involved and, unless the benefits for a grower are large enough, it is unlikely that growers in the southeastern U.S. will adopt the technique.

Summarizing, although in many cases soilborne pest control efficacy in vegetable plasticulture can be maintained by using chemical alternatives to methyl bromide, the real bane of these alternatives, in particular of emulsifiable 1,3-D products, may be the loss of flexibility in terms of longer plant-back periods.

\section{Literature Cited}

Ajwa, H.A, T. Trout, J. Mueller, S. Wilhelm, S.D Nelson, R. Soppe, and D. Shatley. 2002. Application of alternative fumigants through drip irrigation systems. Phytopathology 92:1349-1355.

Brady, N.C. 1974. The nature and properties of soils, p. 639. MacMillan Publ. Co, New York.

Camp, C.R. 1998. Subsurface drip irrigation: A review. Trans. Amer. Soci. Agr. Eng. 41:1353-1367.

Chellemi, D. and J.A. Mirusso. 2002. A new approach to fumigating soils under raised, plastic mulched beds. Annu. Intl. Res. Conf. Methyl Bromide Alternatives and Emissions Reductions, Orlando, Fla. Abstr. 38. http://www.epa. gov/spdpublc/mbr/.

Chen, C., R.E. Green, D.M. Thomas, and J.A. Knuteson. 1995. Modeling 1,3-dichloropropene fumigant volatilization with vapor-phase fumigant volatilization with vapor-phase advection in the soil profile. Environ. Sci. Technol. 29:1816-1821.

Table 1. Relative fumigant concentrations (1,3-D + chloropicrin) in soil air (RFC) at one and four days after drip fumigation at different locations in the bed, Spring 2003, Black Shank Farm Tifton, Ga.

\begin{tabular}{|c|c|c|c|c|c|c|c|c|c|}
\hline \multirow{2}{*}{ Treatment $^{2}$} & \multirow{2}{*}{$\begin{array}{l}\text { Drip } \\
\text { tape }\end{array}$} & \multirow{2}{*}{$\begin{array}{l}\text { Plastic } \\
\text { mulch }\end{array}$} & \multirow[b]{2}{*}{ Rate/ha } & \multirow{2}{*}{\multicolumn{3}{|c|}{$\frac{\text { After } 1 \mathrm{~d}}{\text { Bed location }}$}} & \multirow{2}{*}{\multicolumn{3}{|c|}{$\frac{\text { After } 4 \mathrm{~d}}{\text { Bed location }}$}} \\
\hline & & & & & & & & & \\
\hline 1. InLine & 2 & LDPE & $327 \mathrm{~L}$ & $71 \mathrm{c}^{\mathrm{y}}$ & $79 \mathrm{c}$ & $57 \mathrm{c}$ & $17 \mathrm{c}$ & $18 \mathrm{~b}$ & $14 \mathrm{~b}$ \\
\hline 3. InLine & 1 & LDPE & $327 \mathrm{~L}$ & $145 \mathrm{c}$ & $103 \mathrm{c}$ & $36 \mathrm{c}$ & $30 \mathrm{c}$ & $30 \mathrm{~b}$ & $16 \mathrm{~b}$ \\
\hline 4. InLine & 1 & VIF & $327 \mathrm{~L}$ & $278 \mathrm{~b}$ & $258 \mathrm{~b}$ & $145 \mathrm{~b}$ & $80 \mathrm{~b}$ & $74 \mathrm{a}$ & $64 \mathrm{a}$ \\
\hline 5. Telone EC & 1 & LDPE & $212 \mathrm{~L}$ & $160 \mathrm{c}$ & $129 \mathrm{c}$ & $69 \mathrm{c}$ & $43 \mathrm{c}$ & $35 \mathrm{~b}$ & $22 \mathrm{~b}$ \\
\hline 6. Telone EC & 1 & VIF & $212 \mathrm{~L}$ & $426 \mathrm{a}$ & $368 \mathrm{a}$ & $292 \mathrm{a}$ & $118 \mathrm{a}$ & $84 \mathrm{a}$ & $75 \mathrm{a}$ \\
\hline \multicolumn{10}{|c|}{$F$ probability of contrasts (treatments $1-6)$} \\
\hline \multicolumn{4}{|c|}{ Effect of mulch: LDPE vs. VIF $(1,3,5$ vs., $2,4,6)$} & $<0.01$ & $<0.01$ & $<0.01$ & $<0.01$ & $<0.01$ & $<0.01$ \\
\hline \multicolumn{4}{|c|}{ Effect of drip tape: 1 vs. 2 tapes $(3,4$ vs. 1,2$)$} & NS & NS & 0.01 & NS & NS & NS \\
\hline \multicolumn{4}{|c|}{ Effect of formulation: EC C-35 vs. EC $(3,4$ vs. 5,6$)$} & $<0.01$ & 0.03 & 0.03 & 0.01 & NS & NS \\
\hline
\end{tabular}

${ }^{2}$ Concentrations are relative fumigant concentrations (RFC) expressed as percent relative to initial concentration at $0 \mathrm{~cm}$ depth. InLine and Telone EC were applied from 28 Mar. to 4 Apr.; 1,3-D + chloropicrin gas measurements were taken on 5 and 8 Apr.; center $=1 \mathrm{~cm}$ from the drip tape, middle $=18 \mathrm{~cm}$ from the drip tape, shoulder $=36 \mathrm{~cm}$ from the drip tape. Methyl bromide was chiseled on $28 \mathrm{Mar}$; all beds were covered with plastic mulch immediately following chisel fumigation; drip fumigants were applied over the following days; gas measurements were taken on 5 and 8 Apr.

${ }^{y}$ Data are means of five replications. Means in the same column followed by the same letter are not different $(P=0.05)$ according to Fisher's protected least significance test. No letters indicate nonsignificant difference; ssNonsignificant 
Csinos, A.S., J.E. Laska, and S. Childers. 2002a. Dye injection for predicting pesticide movement in micro-irrigated polyethylene film mulch beds. Pest Mgt. Sci. 58:381-384.

Csinos, A.S., T.M. Webster, D.R. Sumner, A.W. Johnson, C.C. Dowler, and K.W. Seebold. 2002b. Application and crop safety parameters for soil fumigants. Crop Prot. 21:973-982.

Desaeger, J., J. Eger, A. Csinos, J.P. Gilreath, S.M. Olson, and T.M. Webster. 2003. Movement and biological activity of drip-applied 1,3-dichloropropene and chloropicrin in raised beds in the southeastern U.S. Pest Mgt. Sci. 60:1220-1230.

Doherty, B.A and J.C. McKissick. 2002. Georgia farm gate value report. Univ. Ga. College Agr. Environ. Sci. Ext. Ctr. Agribus. Econ. Dev. Publ. AR-02-02 (May).

Dow AgroSciences. 2004c. Labels and safety data sheets. http://www.dowagro.com/usag/.

Florida Agricultural Statistics Service. 2004b. Florida agricultural facts 2004. www.nass.usda. gov/fl/facts/faf04/faf04p.pdf.

Gan, J., S.R. Yates, F.F. Ernst, and W.A. Jury. 2004. Degradation and volatilization of the fumigant chloropicrin after soil fumigation. J. Environ.
Qual. (in press). http://www.pw.ucr.edu/textfiles/manuscript-cp.pdf.

Georgia Automated Environmental Monitoring Network. 2004d. Georgia Automated Environmental Monitoring Network. Www.georgiaweather.net.

Georgia Fruit and Vegetable Growers Association. 2004a. Georgia fruit and vegetable grower news. Summer 2004. www.gfvga.org.

Granberry, D.M., K.A. Harrison, and W.T. Kelley. 1996. Drip chemigation: Injecting fertilizer, acid and chlorine. Univ. Ga. College Agr. Environ. Sci. Coop. Ext. Serv. Bul. 1130. July1996. http:// www.ces.uga.edu/pubcd/b1130-w.html.

Kolbezen, M.J.andF.J.Abu El-Haj. 1977. Permeability of plastic films to fumigants. Proc. Intl. Agr. Plastics Congr., San Diego, Calif. 11-16 Apr.

Lamont, Jr., W.J. 1993. Plastic mulches for production of vegetable crops. HortTechnology 3:35-39.

Leistra, M. and M.J. Frissel. 1975. In: F. Coulston and F. Korte (eds.). Pesticides: Environmental quality and safety, p. 817-828. Suppl. vol III. Thieme Publ., Stuttgart, Germany.

Ma, Q.L., J. Gan, S.K. Papiernik, J.O. Becker, and
S.R.Yates. 2001. Degradation of soil fumigants as affected by initial concentration and temperature. J. Environ. Qual. 30:1278-1286.

Noling, J.W. 1991. Metham sodium application via drip irrigation systems. Fla. Dept. Agr. Consumer Serv. Div. Plant Ind. Nematol. Circ. 196.

Noling, J.W, J.P.Gilreath, and E.N. Rosskopf. 2001. Alternatives to methyl bromide field research efforts for nematode control in Florida. Annu. Intl. Res. Conf. Methyl BromideAlternatives and Emissions Reductions, San Diego, Calif. Abstr. 14. http://www.epa.gov/spdpublc/mbr/.

Noling, J.W. 2002. Reducing methyl bromide field application rates with plastic mulch technology. Entomol. Nematol. Dept., Fla. Coop. Ext. Serv., IFAS Univ. Fla. Document ENY-046. http://edis. ifas.ufl.edu.

Overman, A.J. 1982. Soil fumigation via drip irrigation under full-bed mulch culture for row crops. Proc. Soil and Crop Sci. Soc. Fla. 41:153-155.

Papiernik, S.K. and S.R.Yates. 2001. Transport of fumigant compounds through HDPE and virtually impermeable films. http://mbao.org/2001 proc 016\%20Papiernik\%20SK\%20MeBr\%20confe rence $\% 20$ summary.pdf. 